\title{
Análise de llustrações do Ensino de Biologia no Exame Nacional do Ensino Médio à luz da Teoria Cognitivista da Aprendizagem Multimídia
}

\author{
The Analysis of Illustrations for Biological Education in the National High \\ School Exam in light of the Cognitive Theory of Multimedia Learning
}

\author{
iD Franceline Euzebio Gomes da Silva' \\ Angelina Xavier Silva' \\ Renato Amorim da Silva ${ }^{1}$ \\ Anderson Thiago Monteiro da Silva² \\ Ricardo Ferreira das Neves ${ }^{1}$
}

\begin{abstract}
'Universidade Federal de Pernambuco (UFPE), Centro Acadêmico de Vitória (CAV), Departamento de Biologia, Vitória de Santo Antão, PE, Brasil. Autora Correspondente: franceline.silva@ufpe.br

${ }^{2}$ Universidade Federal Rural de Pernambuco (UFRPE), Programa de Pós-Graduação em Ensino de Ciências e Matemática (PPGEC), Recife, PE, Brasil.
\end{abstract}

Resumo: A pesquisa objetivou analisar as ilustrações relacionadas à área da Biologia presentes no Exame Nacional do Ensino Médio (ENEM) subsidiada pela Teoria Cognitivista da Aprendizagem Multimídia (TCAM), por meio de seu valor instrucional e os possíveis desvios imagéticos. A abordagem de conteúdos do Ensino de Biologia em muitos casos necessita de imagens para mediar o entendimento de estruturas e processos. O ENEM apresenta algumas questões com ilustrações para nortear o texto escrito, todavia podem apresentar equívocos de design ou falta de informações, dificultando a compreensão do enunciado. A TCAM estabelece princípios multimídias para mensurar o valor instrucional de imagens. No ENEM houve ilustrações de Valor Didático com desvios nos Princípios de Coerência e Sinalização. É importante empenhar maior atenção na idealização e inserção de imagens nesses exames e em similares, evitando, assim, ideias equivocadas, que podem influenciar na compreensão da questão e interferir na avaliação do candidato.

Palavras-chave: Exame Nacional do Ensino Médio; Avaliação da aprendizagem; Análise de ilustrações; Ensino de biologia; Teoria Cognitivista da Aprendizagem Multimídia.

Abstract: This research aimed to analyze the illustrations related to the area of Biology presented in the National High School Exam (ENEM), with the subsidy of the Cognitive Theory of Multimedia Learning (CTML), its instructional value and possible imagery deviations. The approach to content in Biology Teaching in many cases needs images to mediate the understanding of structures and processes. ENEM presents some questions with illustrations to guide the navigation of written texts, however they may present design mistakes or lack information, thus making rubrics and instructions difficult to understand. CTML establishes multimedia principles for measuring the instructional value of images. In the ENEM, there were illustrations of Didactic Value with deviations in the Coherence and Signaling Principles. It is important to pay greater attention to the idealization and insertion of images in these exams and alike, in order to avoid misconceptions which can influence the understanding of questions and interfere in the assessment of candidates.

Keywords: National High School Exam; Learning assessment; Analysis of illustrations; Biology teaching; Cognitive Theory of Multimedia Learning.

Recebido em: 09/01/2020

Aprovado em: 22/06/2020 


\section{Introdução}

A imagem representa uma antiga forma de registro da civilização humana, que já expressava suas experiências de vida em paredes de cavernas (SANTAELLA; NÖTH, 2008). Naquela época, ela estava presente nas pinturas rupestres e hoje, ainda, continua permeando o cotidiano humano noutras formas e com informações de valor instrucional (GOMES, 2007). Nesse viés, o conceito de imagem é bastante amplo e polissêmico (BARTHES, 1990), podendo se representar como um objeto ou um fenômeno (SILVA, 2006), ou ainda se caracterizar como "[...] documentos iconográficos ou de ilustrações, incluindo pinturas, gravuras, pôsteres, cartões postais, fotografias, etc." (SMIT, 1996, p. 29).

Considerando essa vasta possibilidade imagética, quando um autor elabora uma ilustração para ser inserida em materiais iconográficos ou multimídias (documentos, livros, vídeos, etc.), por exemplo, ainda que não exista intencionalidade, podem emergir elementos próprios do idealizador, ou seja, o autor pode inferir propriedades e aspectos subjetivos seus e causar obstáculos de interpretação ao leitor (SOUZA, 2011). E, nessa elaboração, pode ocorrer algum distanciamento iconográfico do objeto de origem, devido à busca por uma aproximação mais perceptiva do real. No entanto, por vezes, pode descaracterizar a imagem (SILVA, 2006). Sendo assim, nessa projeção imagética pode haver elementos disformes à perspectiva científica e gerar dificuldades ao sujeito na compreensão do conteúdo, caso não sejam introduzidas adequadamente em materiais instrucionais.

No que tange ao Ensino das Ciências Naturais, muitas dessas imagens representam elementos potenciais para o ensino e a aprendizagem dos estudantes, cuja abordagem de determinados conteúdos, principalmente os abstratos, pode promover ao leitor uma maior aproximação das estruturas e dos processos biológicos à vista desarmada (NEVES, 2015). Corroborando com Smit (1996), existe uma gama de registros iconográficos que, embora possam incitar similaridades, não demandam um mesmo tipo de tratamento, pois seu uso e sua aplicação podem ser distintos. Diante dessa diversidade imagética, exploramos o estudo sobre a ótica do documento iconográfico: as imagens ilustrativas presentes no Exame Nacional do Ensino Médio (ENEM).

O ENEM é uma ferramenta avaliativa que possibilita o ingresso na Educação Superior de estudantes advindos do Ensino Médio. Em suas perguntas observamos várias imagens que, atreladas ao texto escrito, são inseridas no contexto das questões propostas, como potencializadoras de conflitos cognitivos e de argumentações. É delas que remetem a análise e a interpretação de algumas arguitivas, cuja presença auxilia na compreensão de conteúdos da Biologia, entre outras áreas das Ciências. Assim, as imagens podem oportunizar uma visualização pictórica mais "acessível" ao leitor, já que em materiais impressos, a presença imagética apresenta-se como um elemento importante e denota sentido ao contexto abordado e, igualmente, às estruturas linguísticas (KRESS; VAN LEEUWEN, 1996).

Entretanto, nem toda relação estabelecida entre um texto e uma imagem é compreensível ao leitor, e não condiciona a aprendizagem daquilo que se observa, visto que muitas ilustrações podem conter informações deturpadas com equívocos de conceituação, de sinalização, e com imagens distantes do texto, entre outros aspectos. Isso pode vir a comprometer a interpretação do sujeito diante de atividades avaliativas, leituras de livros e observação de vídeos, por exemplo (MAYER, 2005). 
Dessa maneira, a Teoria Cognitivista da Aprendizagem Multimídia (TCAM) busca uma sincronia entre o visual e o verbal em materiais instrucionais, visando a melhoria da aprendizagem. Dessa forma, procura-se uma combinação significativa entre palavras (faladas/escritas) e imagens (gráficos, tabelas, quadros, ilustrações, fotografias, etc.), presentes em livros, testes, documentos, vídeos instrucionais, vídeo aulas, aulas on-line, animações, simulações e jogos interativos (MAYER, 2005). Portanto, indagamos: como as imagens ilustrativas da área da Biologia presentes no ENEM se apresentam à luz da Teoria Cognitivista da Aprendizagem Multimídia?

Por essa razão, a pesquisa procurou analisar as ilustrações relacionadas à área da Biologia presentes no Exame Nacional do Ensino Médio (ENEM) subsidiada pela Teoria Cognitivista da Aprendizagem Multimídia (TCAM), por meio de seu valor instrucional e os possíveis desvios imagéticos. Por fim, este estudo não possui intencionalidade de discriminar ou desconsiderar as imagens ilustrativas presentes no exame, mas apenas contribuir à investigação sobre o ponto de vista imagético e sob a ótica da teoria para o Ensino da Biologia e outras áreas das Ciências.

\section{Considerações sobre o Exame Nacional do Ensino Médio (ENEM)}

O ENEM apresenta caráter voluntário, tendo sua primeira aplicação em 1998, a fim de verificar habilidades e competências dos estudantes que finalizaram a última etapa da Educação Básica - o Ensino Médio - e, assim, direcionar mudanças no processo de avaliação da educação brasileira (INEP, 2009; NASCIMENTO; COUTINHO; PINHEIRO, 2013).

Em 2004, a nota do ENEM passou a ser empregada como forma de entrada de estudantes em Instituições de Ensino Superior (IES) privadas, por meio do Programa Universidade para Todos (PROUNI), através da concessão de bolsas de estudos para aqueles candidatos que obtivessem resultados satisfatórios nessa avaliação (BRASIL, 2005; NASCIMENTO; COUTINHO; PINHEIRO, 2013).

Em 2009, o exame começou a ser empregado como um mecanismo de seleção para o ingresso na Educação Superior, em Universidades Públicas, iniciando um processo de substituição do antigo vestibular, cuja nota serviria como um viés para o acesso a essas IES (INEP, 2009), sendo necessário o cadastro dos estudantes no site do Sistema de Seleção Unificada (SISU). A disputa a uma vaga está atrelada a uma nota mínima (nota de corte) imposta pelas Instituições (BRASIL, 2010).

Vale ressaltar que o ENEM garante atendimento especializado a pessoas com deficiência, gestantes, entre outros, e o candidato que necessitar poderá solicitá-lo no ato da inscrição, propiciando a todos os participantes do exame, equitativas condições para realizar a avaliação (INEP, 2017). Os candidatos menores de 18 anos que estejam cursando o Ensino Médio podem participar do exame apenas para autoavaliação, ou seja, para testar seus conhecimentos, e não poderão utilizá-lo para ingresso na Educação Superior (INEP, 2017).

O antigo modelo do ENEM era composto por 63 questões multidisciplinares e uma redação com texto dissertativo-argumentativo, a partir de uma situação-problema (INEP, 2017). Atualmente, o exame compreende uma redação e um conjunto de 180 questões, estruturadas em quatro blocos: o primeiro está relacionado às Linguagens, os códigos e suas Tecnologias, envolvendo o estudo da Língua Portuguesa por meio da Gramática e da Interpretação de Texto. O segundo enfoca a Língua Estrangeira Moderna, a Literatura, as Artes, a Educação Física e as Tecnologias da Informação. O terceiro aponta para a 
Matemática e suas Tecnologias, as Ciências da Natureza e suas Tecnologias, envolvendo a Química, a Física e a Biologia e, no quarto e último estão as Ciências Humanas e suas tecnologias, englobando a Geografia, a História, a Filosofia e a Sociologia (INEP, 2015).

Algumas questões são constituídas por meio de texto escrito e do uso de ilustrações, buscando exemplificar fenômenos e conceitos aos estudantes. À vista disso, inferimos a necessidade de observação dessas imagens, buscando mensurar o seu valor instrucional e possíveis desvios imagéticos que possam vir a confundir a interpretação das questões pelos candidatos.

\section{O Valor Didático da Imagem mediante a Teoria Cognitivista da Aprendizagem Multimídia (TCAM)}

Richard Mayer é psicólogo e professor da Universidade da Califórnia. Em seus estudos percebeu que o texto, a imagem e o som presentes em materiais instrucionais, possuíam alguns obstáculos para se estabelecer um diálogo coerente nessa tríade, visto que por vezes, alguns materiais apresentavam elementos estranhos e adversos à estrutura cognitiva do sujeito, o que acabava por inviabilizar a compreensão do conteúdo.

Dessa forma, Mayer (2005) estabeleceu a Teoria Cognitivista da Aprendizagem Multimídia (TCAM), que procura inferir parâmetros para mensurar a análise multimídia de diversos materiais instrucionais e seu grau cognitivo. Assim, a partir dela, busca-se uma relação mais intrínseca entre o imagético e o verbal, minimizando possíveis equívocos, contribuindo positivamente para a aprendizagem do sujeito.

O referido autor, observando o potencial multimídia desses materiais e, especificamente, das imagens, estabeleceu cinco postulados que serviram de aportes para o desenvolvimento da teoria. Vejamos:

\footnotetext{
1 - O aluno deve selecionar as palavras mais relevantes que facilitem o processamento na memória operacional verbal; 2 - $\mathrm{O}$ aluno deve selecionar as imagens mais relevantes que facilitem o processamento na memória operacional visual; 3 - $\mathrm{O}$ aluno deve organizar as palavras que já foram selecionadas em um modelo verbal; 4 - O aluno deve organizar as imagens que já foram selecionadas em um modelo visual; 5 - $O$ aluno deve integrar as palavras e imagens no seu conhecimento prévio. (MAYER, 2001 , p. 8 , tradução nossa).
}

Mediante esses postulados, Mayer (2005) estabeleceu alguns Princípios Multimídias que poderiam corroborar com a mensuração do material a ser analisado. Sob esta ótica, captamos as imagens estáticas que confluem com o texto escrito, nas quais pode ser observado o seu valor instrucional - Valor Didático (VD) e Valor não Didático (VnD) -, e também, os possíveis desvios imagéticos, haja vista que algumas ilustrações podem vir a apresentar elementos subjetivos e estranhos à estrutura cognitiva do sujeito, já que partem da idealização do autor e podem contribuir para a construção de obstáculos epistemológicos na compreensão de um determinado conteúdo ao sujeito. Para Bachelard (1996), esses obstáculos epistemológicos são responsáveis pela inércia ou regressão na aquisição do conhecimento, tornando-o mal estabelecido. E ainda, enraíza-se naquele conhecimento que, por vezes, não é questionado. Considerando o viés do contexto imagético, o visualizador da imagem precisa compreendê-la sem haver elementos estranhos, incoerentes ou adversos à sua estrutura cognitiva, para assim, poder questioná-la e entender o seu significado. 
Nessa perspectiva, Mayer (2005) estabeleceu 12 princípios visando reduzir esses equívocos e promover a aprendizagem significativa. Tais princípios estão dispostos em três cargas cognitivas: (1) Redução do Processo Estranho, através da diminuição do excesso de informações irrelevantes e que não colaboram com a aprendizagem (SILVA, 2013); (2) Gerenciamento de Processamento Essencial, por meio da organização de informações essenciais, buscando promover uma representação mental do material apresentado (BARROS, 2013); (3) Promoção de Processamento Generativo, visando promover a retenção e a alocação do conhecimento para outras situações de aprendizagem (SILVA, 2013).

Assim sendo, essas perspectivas norteiam os processos multimídias presentes em muitos materiais didático-pedagógicos utilizados nas aulas, consoante o Quadro 1.

Quadro 1 - Princípios Multimídias estabelecidos por Mayer

\begin{tabular}{|c|c|}
\hline Tipo de Carga & Princípios \\
\hline $\begin{array}{l}\text { Redução de } \\
\text { Processamento } \\
\text { Estranho }\end{array}$ & $\begin{array}{l}\text { - Princípio da Coerência: a aprendizagem ocorre melhor quando materiais e informações estranhas e irrelevantes } \\
\text { (palavras, imagens e sons) são suprimidos. } \\
\text { - Princípio de Sinalização: a aprendizagem ocorre melhor quando são adicionados sinais que destacam a } \\
\text { organização do material. } \\
\text { - Princípio de Contiguidade Espacial: a aprendizagem ocorre melhor quando palavras e imagens são apresentadas } \\
\text { em quadrantes proximais. A informação verbal e gráfica deverá estar em mesma página e não separadas. } \\
\text { - Princípio de Redundância: a aprendizagem ocorre melhor com animação e narração, ao invés de animação, } \\
\text { narração e texto escrito. } \\
\text { - Princípio de Contiguidade temporal: a aprendizagem ocorre melhor quando palavras e imagens são } \\
\text { apresentadas simultaneamente, em vez de sucessivamente. A informação verbal e gráfica deverá ocorrer o } \\
\text { mais sincronicamente possível (imagem e som simultâneos). }\end{array}$ \\
\hline $\begin{array}{l}\text { Gerenciamento } \\
\text { de Processamento } \\
\text { Essencial }\end{array}$ & $\begin{array}{l}\text { - Princípio da Segmentação: a aprendizagem ocorre melhor quando uma aula é apresentada em segmentos } \\
\text { ao estudante e não como uma unidade contínua. } \\
\text { - Princípio de Pré-treinamento: a aprendizagem ocorre melhor quando o estudante recebe pré-treinamento } \\
\text { dos nomes e das características dos principais conceitos. } \\
\text { - Princípio da Modalidade: a aprendizagem ocorre melhor a partir de animação e narração, ao invés de } \\
\text { animação e texto escrito. }\end{array}$ \\
\hline $\begin{array}{l}\text { Promoção de } \\
\text { Processamento } \\
\text { Generativo }\end{array}$ & $\begin{array}{l}\text { - Princípio de Personalização: a aprendizagem ocorre melhor quando as palavras são em estilo de conversação } \\
\text { (coloquial), ao invés de estilo formal. } \\
\text { - Princípio de Voz: a aprendizagem ocorre melhor quando as palavras são faladas por uma simpática voz } \\
\text { humana, ao invés de voz computacional. } \\
\text { - Princípio da Imagem: a aprendizagem ocorre melhor quando a imagem do orador está presente na tela. } \\
\text { - Princípio da Multimídia: a aprendizagem ocorre melhor com palavras e imagens, ao invés de somente palavras. } \\
\text { A informação verbal e gráfica combinadas potencializam os resultados, ao invés de separadas, devendo a } \\
\text { informação ser mais relevante do que a informação verbal. }\end{array}$ \\
\hline
\end{tabular}

Fonte: Mayer (2009, p. 3, tradução nossa).

Seguindo essa vertente, analisamos apenas as ilustrações presentes em um determinado recurso investigado que, em nosso caso, estão registradas nas avaliações do ENEM. No tocante ao que concerne à análise imagética, a TCAM estabelece quatro categorias para classificação de imagens, segundo Mayer (2001 apud COUTINHO; SOARES; BRAGA, 2010, p. 8), são elas:

- Decorativa (D): imagens presentes no texto apenas para fins de entretenimento, sem valor instrucional. Não veiculam discussões ao conteúdo estudado, atuando meramente como um recurso decorativo. Ex: ilustração do tipo propaganda.

- Representacionais (R): imagens com apenas um único elemento. Representação unitária de um organismo vivo, estrutura ou processo. Ilustração unitária ou solitária, sem indicações de partes e elementos constituintes. Ex: imagem que contempla um espermatozoide, mas não indica suas partes constituintes.

- Organizacional (0): imagens com a indicação de partes ou elementos constituintes de um organismo vivo. Ex: imagem que indica a organização da estrutura celular de uma célula eucarionte. 
- Explicativas (E): imagens que explicam a funcionalidade de um sistema. Ilustrações que explicam um ciclo, divisão, reprodução ou processo biológico, que ocorre em um organismo vivo. Ex: imagem que aborda a bomba de $\mathrm{Na}^{-} \mathrm{e} \mathrm{K}^{+}$.

\section{Aspectos Metodológicos}

Para realização do percurso metodológico desta pesquisa, foram selecionadas as avaliações referentes ao Exame Nacional do Ensino Médio (ENEM) entre os anos de 2009 a 2019, sendo analisadas as questões na área das Ciências da Natureza e suas Tecnologias. Para este fim utilizamos os exames de cor amarela, focando apenas nas arguitivas que envolviam ilustrações da área da Biologia, nas quais o candidato precisaria compreendê-las para responder a alternativa adequadamente.

Objetivando classificar as imagens presentes nesse bojo, foram seguidos os critérios propostos por Mayer (2001 apud COUTINHO; SOARES; BRAGA, 2010, p. 8), sendo elas de Valor não Didático (VnD) - Decorativas, Representacionais - e de Valor Didático (VD) Organizacionais e Explicativas. Posteriormente, as ilustrações de VD foram submetidas à análise de três princípios: Coerência, Sinalização e Contiguidade Espacial.

Vale ressaltar que, diante de 12 princípios, apenas os três apontados anteriormente são aplicados em materiais como livros e documentos, pois as imagens presentes são de caráter estático e idealizado, estruturado ou adaptado pelo elaborador. Dessa forma, utilizamos apenas estes, por se enquadrarem nessa perspectiva, e seguirmos as propostas de Coutinho, Soares e Braga (2010), conforme o Quadro 2.

Quadro 2 - Relação entre princípios multimídias e critérios de exclusão das imagens

\begin{tabular}{|l|l|}
\hline \multicolumn{1}{|c|}{ Princípios } & \multicolumn{1}{c|}{ Critérios de Análise } \\
\hline Coerência & $\begin{array}{l}\text { Insatisfátorio quando a imagem apresentar elementos desnecessários, como: antropomorfização, altamente } \\
\text { complexas, desproporcionais ou equívoco conceitual. }\end{array}$ \\
\hline Sinalização & $\begin{array}{l}\text { Insatisfatório quando a imagem apresentar ausência de nitidez das estruturas ou processos, ausência de } \\
\text { setas ou indicações numéricas nos ciclos ou etapas biológicas ou falta de inserções de aviso (cores fantasia } \\
\text { e dimensionalidade). }\end{array}$ \\
\hline Contiguidade Espacial & Insatisfatório quando a imagem e o texto escrito não ocuparem um mesmo quadrante ou um quadrante próximo. \\
\hline
\end{tabular}

Fonte: Adaptado de Coutinho, Soares e Braga (2010, p. 10).

À vista disso, a percepção dos desvios em alguns princípios multimídias descritos anteriormente possibilita a reflexão dos obstáculos epistemológicos (BACHELARD, 1996; NEVES, 2015) que podem intervir na compreensão do estudante e, com isso, no desenvolvimento de barreiras para aprendizagem do conteúdo. Por fim, consideramos na análise das imagens no ENEM, aquelas de cunho ilustrativo, ou seja, as que são elaboradas por seus idealizadores, com cores, formas, dimensionalidade, etc., não se enquadrando nessa pesquisa fotografias, quadros, tabelas ou gráficos.

\section{Resultados e Discussões}

Inicialmente, selecionamos as avaliações do ENEM de cor amarela referente às edições de 2009 a 2019. Nelas foram analisados quesitos alocados na área das Ciências da Natureza e suas Tecnologias, com enfoque para os conteúdos biológicos. Vale ressaltar que nos anos de 2015, 2016 e 2017, houve necessidade do Governo Federal reaplicar o ENEM, considerando 
que nesse período ocorreram situações adversas que acabaram por dificultar a participação de muitos estudantes no exame, como ocupações em escolas e enchentes em alguns locais do país. Diante disso, também foram contempladas essas avaliações e suas imagens nesta pesquisa.

Após isso, realizamos um panorama geral das ilustrações presentes nesses exames, no que concernem ao ano, subáreas, conteúdos e disciplinas relacionadas, segundo o Quadro 3.

Quadro 3 - Panorama geral das imagens presentes no ENEM - 2009 a 2019 e Reaplicações para a área da Biologia

\begin{tabular}{|c|c|c|c|c|}
\hline $\begin{array}{l}\text { Ano do } \\
\text { Exame }\end{array}$ & $\begin{array}{c}N^{\circ} \text { da } \\
\text { Questão }\end{array}$ & Subárea & Conteúdo & Correlação entre as Disciplinas \\
\hline \multirow[t]{3}{*}{2009} & 16 & Genética & DNA & Genética Mendeliana \\
\hline & 22 & Genética & Ciclo de geração de indivíduos & Biologia Celular e Genética mendeliana \\
\hline & 33 & Evolução & Teoria evolutiva da pelagem & Ecologia e Zoologia \\
\hline \multirow[t]{4}{*}{2010} & 60 & Geologia & Solo, magma, vulcão, calor & Ecologia e Geologia \\
\hline & 66 & $\begin{array}{l}\text { Fisiologia } \\
\text { humana }\end{array}$ & Função das microvilosidades no intestino & Biologia celular e Fisiologia Humana \\
\hline & 77 & Ecologia & Ecossistemas & Ecologia, Botânica e Zoologia \\
\hline & 90 & Histologia & $\begin{array}{l}\text { Modificação genética (organismos } \\
\text { geneticamente modificados) }\end{array}$ & Genética e Zoologia \\
\hline \multirow[t]{3}{*}{2011} & 48 & Ecologia & Cadeia alimentar & Ecologia e Zoologia \\
\hline & 65 & Parasitologia & Malária & Ecologia e Educação em Saúde \\
\hline & 89 & Ecologia & Aquecimento global & Ecologia e Zoologia \\
\hline \multirow[t]{3}{*}{2012} & 71 & Ecologia & Interação entre animais e plantas & Botânica e Zoologia \\
\hline & 77 & $\begin{array}{l}\text { Biologia } \\
\text { Celular }\end{array}$ & Interação entre soluções & Biofísica e Química \\
\hline & 81 & Botânica & Evolução das estruturas das plantas & Botânica e Evolução \\
\hline \multirow[t]{2}{*}{2013} & 47 & $\begin{array}{l}\text { Fisiologia } \\
\text { humana }\end{array}$ & $\begin{array}{l}\text { Circulação sanguínea com o método } \\
\text { torniquete }\end{array}$ & Anatomia humana e Fisiologia \\
\hline & 73 & Genética & Carga genética com ênfase na paternidade & Genética Mendeliana \\
\hline \multirow[t]{5}{*}{2014} & 48 & Genética & $\begin{array}{l}\text { Ciclo de replicação de bactéria e inserção } \\
\text { no tecido de uma planta }\end{array}$ & Bacteriologia, Fisiologia vegetal e Zoologia \\
\hline & 57 & Genética & Carga genética associada à doença & Genética Mendeliana e Lógica \\
\hline & 62 & Zoologia & $\begin{array}{l}\text { Reações químicas e estrutura dos } \\
\text { esqueletos calcários dos corais }\end{array}$ & Química e Zoologia \\
\hline & 69 & Zoologia & $\begin{array}{l}\text { Ciclo de vida de insetos parasitoides } \\
\text { (ênfase na cadeia alimentar) }\end{array}$ & Ecologia e Zoologia \\
\hline & 88 & Imunologia & Produção e aplicação de imunobiológicos & Imunologia e Zoologia \\
\hline 2015 & --- & --- & --- & --- \\
\hline $\begin{array}{c}2015 \\
\text { (reaplicação) }\end{array}$ & --- & --- & --- & --- \\
\hline \multirow[t]{3}{*}{2016} & 75 & Bioquímica & Produção de etanol & Biologia e Química \\
\hline & 81 & Microbiologia & Mecanismo de efeito de vacina & Biologia Celular e Microbiologia \\
\hline & 87 & Botânica & Transporte da seiva & Química e Fisiologia Vegetal \\
\hline $\begin{array}{l}2016 \\
\text { (reaplicação) }\end{array}$ & --- & --- & --- & --- \\
\hline 2017 & 98 & $\begin{array}{l}\text { Biologia } \\
\text { Celular }\end{array}$ & Membrana Plasmática & Biologia Celular e Imunologia \\
\hline $\begin{array}{l}2017 \\
\text { (reaplicação) }\end{array}$ & 128 & Evolução & Árvore Filogenética & Genética e Zoologia \\
\hline
\end{tabular}




\begin{tabular}{|c|c|c|c|c|}
\hline $\begin{array}{l}\text { Ano do } \\
\text { Exame }\end{array}$ & $\begin{array}{l}\text { No da } \\
\text { Questão }\end{array}$ & Subárea & Conteúdo & Correlação entre as Disciplinas \\
\hline \multirow[t]{4}{*}{2018} & 114 & Genética & Metabolismo Celular & Biologia Celular e Genética mendeliana \\
\hline & 120 & Genética & Especiação & Ecologia e Genética mendeliana \\
\hline & 130 & Genética & Genótipo e alelos & Botânica e Genética mendeliana \\
\hline & 134 & Bioquímica & Oxidação de Combustíveis & Bioquímica e Ecologia \\
\hline \multirow[t]{4}{*}{2019} & 103 & Genética & Visão & Biofísica e Genética mendeliana \\
\hline & 112 & $\begin{array}{l}\text { Biologia } \\
\text { Celular }\end{array}$ & Bicamada lipídica & Biologia Celular e Bioquímica \\
\hline & 123 & Bioquímica & Diabetes & Biologia Celular e Química \\
\hline & 128 & Evolução & $\begin{array}{l}\text { Diversidade de plantas e ambiente } \\
\text { terrestre }\end{array}$ & Botânica e Evolução \\
\hline
\end{tabular}

Nota: ENEM 2015 e 2015 (Reaplicação) e ENEM 2016 (Reaplicação) não apresentaram questões com uso de ilustrações para a área da Biologia.

Fonte: elaborado pelos autores.

Considerando-se o período de execução do exame, entre 2009 a 2019, e as reaplicações em 2015, 2016 e 2017, houve um total de 33 ilustrações utilizadas para nortear as questões das subáreas da Biologia, sendo que a sua distribuição variou entre três a cinco questões. Vale ressaltar que, no ano 2015, 2015 (reaplicação) e 2016 (reaplicação), não se detectou uso de imagens, mas apenas questões com textos, entre outras propostas. Mayer (2005) aponta que o estudante compreende melhor a relação entre texto-imagem do que apenas texto. Assim, dependendo da questão, o sujeito teria melhores condições de responder ao enunciado proposto, com o uso de uma ilustração para contextualizar a arguitiva.

Durante esse período, considerando as subáreas da Biologia, a Genética obteve maior evidência no exame, com nove citações. Já os conteúdos disciplinares surgiram diferentemente a cada ano, não seguindo um padrão. Para a resposta às arguitivas nos exames, os conteúdos abordados necessitavam uma correlação com outra área do conhecimento, sendo a subárea Zoologia com maior ênfase, com onze citações.

Após a descrição acima, partimos para análise das ilustrações, empregando a classificação de Valor não Didático (VnD) e Valor Didático (VD), em quatro categorias: Decorativas (D), Representacionais (R), Organizacionais (O) e Explicativas (E), conforme Mayer (2001 apud COUTINHO; SOARES; BRAGA, 2010, p. 8), mencionadas na Tabela 1.

Tabela 1 - Descrição das ilustrações de Valor não Didático (VnD) - Decorativas (D) e Representacionais (R) - e Valor Didático (VD) - Organizacionais (O) e Explicativas (E) - em questões do Enem na área de Biologia

\begin{tabular}{|c|c|c|c|c|c|c|c|c|c|}
\hline \multirow[t]{2}{*}{ Ano do Exame } & \multicolumn{6}{|c|}{ VnD } & \multicolumn{2}{|r|}{ VD } & \multirow{2}{*}{$\begin{array}{c}\text { Quantidade } \\
\text { de imagens } \\
\text { VnD e VD }\end{array}$} \\
\hline & D & $\begin{array}{c}\mathbf{N}^{\circ} \\
\text { Questão }\end{array}$ & $\mathbf{R}$ & $\begin{array}{c}\mathbf{N}^{\circ} \\
\text { Questão }\end{array}$ & 0 & $\begin{array}{c}\mathbf{N}^{\circ} \\
\text { Questão }\end{array}$ & $\mathbf{E}$ & $\begin{array}{c}\mathrm{N}^{\circ} \\
\text { Questão }\end{array}$ & \\
\hline 2009 & 0 & - & 0 & - & 1 & 33 & 2 & 16,22 & 3 \\
\hline 2010 & 0 & - & 1 & 77 & 1 & 66 & 2 & 60,90 & 4 \\
\hline 2011 & 0 & - & 1 & 48 & 1 & 65 & 1 & 89 & 3 \\
\hline 2012 & 0 & - & 0 & - & 1 & 77 & 2 & 71,81 & 3 \\
\hline 2013 & 0 & - & 1 & 47 & 1 & 73 & 0 & - & 2 \\
\hline 2014 & 0 & - & 1 & 57 & 0 & - & 4 & $48,62,69,88$ & 5 \\
\hline 2015 & 0 & - & 0 & - & 0 & - & 0 & - & 0 \\
\hline 2015 Reaplicação & 0 & - & 0 & - & 0 & - & 0 & - & 0 \\
\hline
\end{tabular}




\begin{tabular}{|c|c|c|c|c|c|c|c|c|c|}
\hline \multirow[t]{2}{*}{ Ano do Exame } & \multicolumn{6}{|c|}{ VnD } & \multicolumn{2}{|r|}{ VD } & \multirow{2}{*}{$\begin{array}{l}\text { Quantidade } \\
\text { de imagens } \\
\text { VnD e VD }\end{array}$} \\
\hline & D & $\begin{array}{c}\text { No }^{\circ} \\
\text { Questão }\end{array}$ & $\mathbf{R}$ & $\begin{array}{c}\text { No }^{\circ} \\
\text { Questão }\end{array}$ & 0 & $\begin{array}{c}\mathbf{N}^{\circ} \\
\text { Questão }\end{array}$ & $\mathbf{E}$ & $\begin{array}{c}\mathbf{N}^{\circ} \\
\text { Questão }\end{array}$ & \\
\hline 2016 & 0 & - & 0 & - & 0 & - & 3 & $75,81,87$ & 3 \\
\hline 2016 Reaplicação & 0 & - & 0 & - & 0 & - & 0 & - & 0 \\
\hline 2017 & 0 & - & 0 & - & 0 & - & 1 & 98 & 1 \\
\hline 2017 Reaplicação & 0 & - & 1 & 128 & 0 & - & 0 & - & 1 \\
\hline 2018 & 0 & - & 1 & 130 & 1 & 114 & 2 & 120,134 & 4 \\
\hline 2019 & 0 & - & 1 & 103 & 1 & 112 & 2 & 123,128 & 4 \\
\hline Total & 0 & & 7 & & 7 & & 19 & & 33 \\
\hline
\end{tabular}

Nota: ENEM 2015 e 2015 (Reaplicação) e ENEM 2016 (Reaplicação) não apresentaram questões com uso de ilustrações para a área da Biologia.

Fonte: elaborado pelos autores.

Inicialmente, vale ressaltar que o ENEM dos anos de 2015, 2015 (reaplicação) e 2016 (reaplicação) não apresentaram imagens no que tange à área da Biologia para contextualizar o texto escrito. Nesse caso, não se percebeu o real motivo para não haver a presença imagética, uma vez que a ilustração corroboraria com um melhor entendimento do texto, principalmente, quando relacionados a conceitos e processos biológicos abstratos. Acreditamos que essa escolha está direcionada a um interesse do próprio idealizador, já que nas demais áreas das Ciências Naturais houve uso de imagens.

Em linhas gerais, houve um quantitativo de 33 imagens em questões do ENEM durante os anos de 2009 a 2019 e as reaplicações de 2015, 2016 e 2017, exceto os anos das avaliações destacadas anteriormente. Porquanto, houve um menor uso de ilustrações com VnD (Decorativas e Representacionais) e maior número das imagens de VD (Organizacionais e Explicativas) nesses ENEM para a área da Biologia.

Considerando as imagens de $\mathrm{VnD}$ houve um quantitativo de sete Representacionais e nenhuma Decorativa em todos os anos de aplicação dos exames. Esse fato é bastante pertinente, pois conforme orienta Mayer (2005), o uso de ilustrações de VnD (Decorativas e Representacionais) devem ser sempre em menor quantidade, visto que elas não fornecem informações relevantes a quem ler, pois direcionam o leitor a um momento de entretenimento ou expressam apenas uma visão unitária, sem maiores significâncias ao conteúdo. Desse modo, a sua presença deve ser mínima ou ausente, porque não estimulam os processos cognitivos do sujeito, e, por vezes, pode sobrecarregá-lo com informações irrelevantes (NEVES, 2015).

Já as imagens de VD, nesses exames, obtiveram maior representatividade em relação às de $\mathrm{VnD}$, sendo sete Organizacionais e 19 Explicativas. Assim, quando presente, as imagens de VD podem vir a estimular o processo de ensino-aprendizagem, oportunizando o conflito cognitivo e reflexões sobre as informações apresentadas, confluindo para um melhor entendimento do conteúdo ao sujeito (MAYER, 2005), já que essas ilustrações de VD demonstram ao leitor a estrutura organizacional de um ser vivo e seus processos, assim como as relações biológicas envolvidas (COUTINHO; SOARES; BRAGA, 2010; NEVES, 2015).

Considerando que as ilustrações com VD foram mais representativas ao longo dos anos no ENEM, e que esses tipos de imagens são relevantes aos processos de ensinoaprendizagem, elas podem conter elementos estranhos e gerar obstáculos epistemológicos ao sujeito, caracterizando o que chamamos de desvio imagético (NEVES, 2015). Sendo assim, Mayer (2005) esclarece que as imagens de VD precisam ser mensuradas a partir de princípios instrucionais, os Princípios Multimídias. 
Nesse caso, como as ilustrações são de caráter estático (documentos, livros, manuais, etc.), a sua análise é submetida a apenas três dos 12 princípios destacados por Mayer, conforme o Quadro 1. As imagens de VD nas edições do ENEM de 2009 a 2019 e reaplicações foram analisadas por meio dos Princípios de Coerência, Sinalização e Contiguidade Espacial, utilizando como referência as perspectivas de Coutinho, Soares e Braga (2010).

Para tanto, na Tabela 2 disponibilizamos o quantitativo de ilustrações que apresentaram desvios imagéticos, isto é, foram insatisfatórias, ferindo os princípios referenciados anteriormente, segundo as perspectivas da TCAM.

Tabela 2 - Imagens de VD (Organizacionais - O e Explicativas - E) que apresentaram desvios nos princípios de Coerência, de Sinalização e de Contiguidade Espacial

\begin{tabular}{|c|c|c|c|c|c|c|c|c|c|c|c|c|}
\hline \multirow{2}{*}{ Ano do Exame } & \multicolumn{6}{|c|}{ VD (0) } & \multicolumn{5}{|c|}{ VD (E) } & \multirow{2}{*}{$\begin{array}{c}\text { Quantidade } \\
\text { de Imagens } \\
\text { com } \\
\text { Desvios }\end{array}$} \\
\hline & PC & $\begin{array}{c}\mathrm{N}^{\circ} \\
\text { Questão }\end{array}$ & PS & $\begin{array}{c}\mathrm{N}^{\circ} \\
\text { Questão }\end{array}$ & PCE & $\begin{array}{c}\mathbf{N}^{\circ} \\
\text { Questão }\end{array}$ & PC & $\begin{array}{c}\mathrm{N}^{\circ} \\
\text { Questão }\end{array}$ & PS & $\begin{array}{c}\text { No }^{\circ} \\
\text { Questão }\end{array}$ & PCE & \\
\hline 2009 & 0 & - & 0 & - & 0 & - & 0 & - & 0 & - & 0 & 0 \\
\hline 2010 & 0 & - & 0 & - & 0 & - & 0 & - & 0 & - & 0 & 0 \\
\hline 2011 & 0 & - & 1 & 65 & 0 & - & 0 & - & 1 & 89 & 0 & 2 \\
\hline 2012 & 0 & - & 1 & 77 & 0 & - & 0 & - & 1 & 81 & 0 & 2 \\
\hline 2013 & 0 & - & 0 & - & 0 & - & 0 & - & 0 & - & 0 & 0 \\
\hline 2014 & 0 & - & 0 & - & 0 & - & 1 & $48 *$ & 3 & $\begin{array}{l}48 *, 69 \\
88\end{array}$ & 0 & 3 \\
\hline 2015 & 0 & - & 0 & - & 0 & - & 0 & - & 0 & - & 0 & 0 \\
\hline 2015 Reaplicação & 0 & - & 0 & - & 0 & - & 0 & - & 0 & - & 0 & 0 \\
\hline 2016 & 0 & - & 0 & - & 0 & - & 0 & - & 2 & 81,87 & 0 & 2 \\
\hline 2016 Reaplicação & 0 & - & 0 & - & 0 & - & 0 & - & 0 & - & 0 & 0 \\
\hline 2017 & 0 & - & 0 & - & 0 & - & 0 & - & 0 & - & 0 & 0 \\
\hline 2017 Reaplicação & 0 & - & 0 & - & 0 & - & 0 & - & 0 & - & 0 & 0 \\
\hline 2018 & 0 & - & 1 & 114 & 0 & - & 1 & 120 & 0 & - & 0 & 2 \\
\hline 2019 & 0 & - & 0 & - & 0 & - & 0 & - & 1 & 128 & 0 & 1 \\
\hline Total & 0 & & 3 & & 0 & & 2 & & 7 & & 0 & 12 \\
\hline
\end{tabular}

Nota: ENEM 2015 e 2015 (Reaplicação) e ENEM 2016 (Reaplicação) não apresentaram questões com uso de ilustrações para a área da Biologia.

*A imagem 48/2014 apresentou duplicidade de desvios (Princípio de Coerência e Sinalização).

Fonte: elaborado pelos autores.

A partir da tabela acima, obtivemos um total de 12 questões que apresentaram imagens de Valor Didático, no que tangue à Biologia e que apresentaram desvios imagéticos em avaliações do ENEM, sendo a Organizacional com apenas duas ilustrações, e a Explicativa com nove. Desse mote, apenas os Princípios de Coerência e de Sinalização apresentaram equívocos imagéticos, sendo dois e onze, respectivamente.

Mayer (2005) esclarece que uma imagem apresenta desvio no Princípio de Coerência (PC), quando os elementos que a compõem contêm material supérfluo, irrelevante ou antropomorfizado, podendo confundir a interpretação do sujeito. Em vista disso, a aprendizagem é melhor quando esse tipo de material é suprimido (COUTINHO; SOARES; BRAGA, 2010). Esse tipo de material irrelevante desvia a atenção dos componentes importantes da imagem dificultando a aprendizagem, direcionando o sujeito a organizar ideias inapropriadas sobre o tema (MAYER, 2005).

Considerando os desvios no Princípio de Sinalização (PS), Mayer (2005) discorre que a ausência de informações sobre a coloração, dimensionalidade, setas ou numerações 
nas ilustrações comprometem o entendimento e pode levar o leitor a um equívoco na interpretação do enunciado. Corroborando com essa afirmação, Barbosa et al. (2012), orientam que o uso de técnicas sinalizadoras ajudam o leitor a focar nas informações relevantes presentes na imagem.

Diferentemente, o Princípio de Contiguidade Espacial (PCE) não apresentou desvio imagético nas ilustrações de VD do ENEM da área da Biologia. Mayer (2005) orienta que as imagens em manuais, documentos e livros devem se encontrar em quadrante igual ou próximo ao texto escrito. Isso ocorreu em todas as imagens analisadas, confluindo com as orientações da TCAM.

No Quadro 4 observa-se a descrição das imagens que apresentaram desvios em algumas avaliações do ENEM, no que tange ao Princípio de Coerência e de Sinalização.

\section{Quadro 4 - Descrição das Imagens de VD que apresentaram desvios com relação aos Princípios de Coerência e de Sinalização em avaliações do ENEM para a área da Biologia}

\begin{tabular}{|c|c|}
\hline & Descrição dos Desvios Imagéticos \\
\hline 2011 & $\begin{array}{l}\text { Questões } 65 \text { e } 89 \text { - As arguitivas compreendiam imagens do tipo Organizacional e Explicativa, respectivamente, nas } \\
\text { quais apresentaram desvio no Princípio de Sinalização. } \\
\text { A primeira arguitiva considerou uma ilustração de um Mapa-Múndi, com informações sobre a ocorrência de casos de } \\
\text { malária em todos os continentes. Embora houvesse destaque de sombreamentos nas áreas, legendas e fonte da origem } \\
\text { imagética, todavia a questão não valorizou/apresentou informações quanto à dimensionalidade da imagem. } \\
\text { A segunda arguitiva veicula um 'desenho' por meio de uma história em quadrinhos com uso de animais, remetendo ao } \\
\text { leitor uma reflexão sobre a culpa do aquecimento global. Todavia, a proposta não apresentava legendas e nem informações } \\
\text { que destacassem a dimensionalidade da imagem. }\end{array}$ \\
\hline 2012 & $\begin{array}{l}\text { Questões } 77 \text { e } \mathbf{8 1} \text { - As arguitivas compreendiam imagens do tipo Organizacional e Explicativa, respectivamente, sendo } \\
\text { ambas com desvio no Princípio de Sinalização. } \\
\text { A primeira arguitiva expunha uma estrutura celular denominada Lipossomo com uma dimensionalidade significativamente } \\
\text { maior e diferentemente do referente real, o qual se apresentaria numa forma bastante diminuta, necessitando de } \\
\text { instrumentos específicos para ser observado. Percebe-se a ausência de legenda ou informes que explicitassem ao leitor } \\
\text { a necessidade do aumento da estrutura. } \\
\text { A segunda arguitiva designava o processo de evolução de plantas e as exemplificou com imagens pequenas e de pouca } \\
\text { nitidez. Percebe-se a ausência de legenda ou informes acerca da dimensionalidade dos organismos, falta de adequação } \\
\text { na forma e coloração da imagem (preto e branco), com pouca nitidez não permitindo que o leitor possa observá-las com } \\
\text { maior percepção de detalhes, de forma que alguns elementos podem passar despercebidos. }\end{array}$ \\
\hline 2014 & $\begin{array}{l}\text { Questões 48, } 69 \text { e } \mathbf{8 8} \text { - As arguitivas compreendiam imagens do tipo Explicativa, sendo a primeira com desvio no } \\
\text { Princípio de Coerência e Sinalização, enquanto a segunda e a terceira, apenas no Princípio de Sinalização. } \\
\text { A primeira arguitiva envolvia a discussão sobre o processo de obtenção de organismos geneticamente modificados } \\
\text { (OGMs) através da transferência de uma parte do material genético bacteriano para plantas, com objetivo de promover } \\
\text { a resistência do vegetal às pragas. Considerando o desvio no Princípio de Coerência - a imagem disponibilizava uma } \\
\text { ilustração com'desenhos': um organismo 'bactéria', o DNA bacteriano e um tipo de planta. O organismo apresenta uma } \\
\text { estrutura semelhante ao núcleo, característico de organismos eucariotos, cujo material genético deveria está imerso } \\
\text { e disperso no citoplasma. Quanto ao modelo do DNA, observa-se uma dupla hélice linear, entretanto, os procariotos } \\
\text { apresentam uma dupla hélice em formato circular. Por fim, nos processos biotecnológicos e da engenharia genética para } \\
\text { extração e inserção do gene de interesse, percebe-se a ausência de elementos que permitissem ao leitor identificar com } \\
\text { clareza esses procedimentos. Considerando o desvio no Princípio de Sinalização, não houve informações ou legenda } \\
\text { que destacassem a dimensionalidade dos organismos e estruturas, contudo estes seriam um esboço em forma e tamanho, } \\
\text { do referente real. } \\
\text { A segunda arguitiva estava relacionada ao ciclo de vida de um inseto parasita de lagartas. A imagem apresentada também } \\
\text { utilizou organismos cujos tamanhos não apresentam informações ou legendas sobre o aumento na dimensionalidade } \\
\text { para uma melhor visualização. } \\
\text { A terceira arguitiva representava o processo da produção de vacinas. Igualmente às imagens anteriores, apresentou } \\
\text { tamanho de organismos divergente do seu referencial real, não havendo nenhum tipo de destaque ou informação em } \\
\text { legenda, por exemplo, quanto a isso. }\end{array}$ \\
\hline 2016 & $\begin{array}{l}\text { Questões } \mathbf{8 1} \text { e } \mathbf{8 7} \text { - As arguitivas incluíam imagens do tipo Explicativas, sendo ambas com desvio no Princípio de } \\
\text { Sinalização. } \\
\text { A primeira arguitiva discorria sobre os mecanismos de exclusão de patógenos pela ação de probióticos no intestino } \\
\text { de um animal. Novamente, o tamanho da estrutura não foi destacado como um aumento na dimensionalidade, com vista } \\
\text { a melhor observação. Existe necessidade de legenda ou informações no enunciado da arguitiva. Vale ressaltar que, no } \\
\text { texto original, no qual foi extraída a imagem, também não apresenta tal informação. } \\
\text { A segunda arguitiva abordava sobre o movimento da seiva xilêmica em uma planta. As representações imagéticas } \\
\text { desta arguitiva não apresentam indicação ou legenda das dimensões reais dos organismos, fugindo da dimensão original. } \\
\text { Nota-se que no texto de referência tal destaque também não estava explicitado. }\end{array}$ \\
\hline
\end{tabular}




\begin{tabular}{|c|c|}
\hline $\begin{array}{l}\text { Ano do } \\
\text { Exame }\end{array}$ & Descrição dos Desvios Imagéticos \\
\hline 2018 & $\begin{array}{l}\text { Questões } 114 \text { e } 120 \text { - As arguitivas compreenderam imagens do tipo Organizacional e Explicativa, respectivamente, } \\
\text { com desvio no Princípio de Sinalização e Coerência, respectivamente. } \\
\text { A primeira arguitiva depreendia sobre o processo de metabolismo celular com imagens de uma célula sem destaque } \\
\text { a membrana e ao citoplasma, mas com representação do núcleo e de alguns compartimentos celulares. Nesse caso, não } \\
\text { houve legendas ou informações sobre a dimensionalidade das estruturas. Entretanto, representaria apenas um esboço em } \\
\text { forma e tamanho, procurando se aproximar do referente real, visto que a célula como outros organismos microscópicos } \\
\text { não podem ser observados a vista desarmada, havendo necessidade de instrumentos técnicos para a sua visualização. } \\
\text { A segunda arguitiva demonstrava por meio de um esquema a formação de novas espécies por meio do cruzamento } \\
\text { entre diferentes populações. O esquema bastante complexo com setas que cruzam entre as espécies, tornando o modelo } \\
\text { de difícil compreensão. O uso de várias setas e sentidos aumentou a complexidade do esquema e, consequentemente, } \\
\text { sobrecarrega a capacidade cognitiva e pode ocasionar uma interpretação incorreta pelo sujeito. }\end{array}$ \\
\hline 2019 & $\begin{array}{l}\text { Questão } 128 \text { - A arguitiva compreendeu uma imagem do tipo Explicativa, com desvio no Princípio de Sinalização. } \\
\text { A arguitiva propunha uma árvore filogenética de diferentes grupos de plantas discutindo sobre as características que as } \\
\text { levaram a conquista do ambiente terrestre. A imagem utilizou de 'desenhos' de grupos vegetais numa dimensionalidade } \\
\text { divergente da real, sem nenhuma legenda ou informação em destaque. }\end{array}$ \\
\hline
\end{tabular}

Fonte: elaborado pelos autores.

Em linhas gerais, notamos que nas edições do ENEM de 2011, 2012, 2014, 2016, 2018 e 2019 houve 12 questões que apresentaram ilustrações de Valor Didático (Organizacionais e Explicativas), bem como desvios imagéticos, no Princípio de Coerência e/ou no Princípio de Sinalização.

Nesses casos, percebemos nessas questões, imagens com ausência de destaque textual quanto à dimensionalidade das estruturas apresentadas, e falta de legendas com informações que oportunizassem uma interpretação imagética junto ao texto, mais compreensível acerca do conteúdo abordado. Representação de organismos e estruturas bastante divergentes do referente real, podendo contribuir com equívocos conceituais, e estruturação de esquema complexo, podendo gerar equívocos interpretativos e conceituais, devido à organização e à elaboração do design ilustrativo.

Diante do exposto, é importante o cuidado na elaboração e na inserção de imagens na mediação da abordagem dos conteúdos, pois pode induzir o sujeito a uma percepção desproporcional do tamanho do referente real, estimulando uma visão destorcida da Biologia (NEVES, 2015). Além do que, como corrobora Barthes (1990), a imagem em si é polissêmica, e cada pessoa, ao observá-la, pode construir diversas interpretações. Assim, existe a necessidade de cautela e atenção quanto a sua aplicação no processo de ensinoaprendizagem (SILVA, 2006), ou em qualquer proposta de caráter informativo ou instrucional.

\section{Considerações Finais}

Os Princípios Multimídias estabelecidos por Mayer e utilizados nesta pesquisa como aporte para análise de imagens da área da Biologia presentes nas questões do Exame Nacional do Ensino Médio (ENEM), possibilitaram ressaltar o potencial imagético e sua significância no desenvolvimento cognitivo do estudante, oportunizando reflexão sobre a sua presença em processos avaliativos. A pesquisa procurou contribuir sobre a relevância da inserção de ilustrações em materiais, de forma cautelar, no sentido de facilitar a compreensão do conteúdo teórico e/ou explicar fenômenos de forma didática no exame.

Considerando que o ENEM representa o principal meio de ingresso de estudantes na Educação Superior, torna-se necessário que as idealizações imagéticas sejam estruturadas através de algum aporte teórico-metodológico, já que não representa apenas um recurso figurativo, mas é por meio delas que o estudante pode, em alguns contextos, confundir as ideias e ser penalizado durante o seu processo avaliativo. Por conseguinte, as ilustrações 
presentes nas questões do ENEM precisam apresentar elementos coerentes e entendíveis à estrutura cognitiva do candidato, proporcionando um melhor aproveitamento dessas questões durante o exame.

Diante dos resultados apresentados, observamos que o ENEM apresentou para a área da Biologia, uma representação pouco significativa de ilustrações em seu processo avaliativo. As imagens tinham, em sua maioria, Valor Didático e algumas apresentaram desvios imagéticos suficientes para gerar obstáculos ao processo cognitivo do sujeito. Isso sugere maior atenção, quanto à idealização de uma ilustração, para não potencializar inferências equívocas ao leitor e, com isso, evitar a ocorrência de respostas incorretas concebidas a partir dos desvios imagéticos, visto que, o próprio processo de avaliação gera nervosismo e frustração ao estudante.

Vale ressaltar que os idealizadores optaram pela mudança da coloração das imagens da área da Biologia utilizadas no ENEM, usando imagens em branco e preto, o que, em parte, diminuiu a percepção imagética e comprometeu a observação de detalhes de estruturas e organismos representados nessas questões. Adicionalmente, a ausência de nitidez, consequentemente, pode ter sido um obstáculo na compreensão do enunciado, estimulando possíveis equívocos de interpretação.

Dessarte, é importante o desenvolvimento de novos estudos que contemplem outras áreas das Ciências, a fim de balizar novas perspectivas nesse exame ou em outras propostas avaliativas, e contribuir para a minimização de obstáculos na aprendizagem. As pesquisas orientadas por esse contexto podem contribuir significativamente para uma melhor discussão e construção do conhecimento. Além disso, podem vir a instruir para a seleção de ilustrações, estabelecendo critérios de escolha que favoreçam a percepção cognitiva do estudante.

\section{Referências}

BACHELARD, G. A formação do espírito científico. Rio de janeiro: Contraponto, 1996.

BARBOSA, J. L. B. et al. Aprendendo mitose e meiose de forma simples: proposta de jogo didático. In: ENCONTRO NACIONAL DE ENSINO DE BIOLOGIA, 4., E ENCONTRO REGIONAL DE ENSINO DE BIOLOGIA, 2., 2012, Goiânia. Anais [...]. Goiânia: ENEBIO: EREBIO, 2012. 1 CD-ROM.

BARROS, A. P. R. M. Contribuições de um micromundo composto por recursos do GeoGebra e da coleção $M^{3}$ para a aprendizagem do conceito de volume de pirâmide. 2013. 184 f. Dissertação (Mestrado em Ensino de Ciências e Matemática) - Faculdade de Educação, Universidade Estadual de Campinas, Campinas, 2013.

BARTHES, R. O óbvio e o obtuso: ensaios críticos III. Rio de Janeiro: Nova Fronteira, 1990.

BRASIL. Lei no 11.096, em 13 de janeiro de 2005. Institui o Programa Universidade para Todos PROUNI, regula a atuação de entidades beneficentes ... Diário Oficial da União, Brasília, 14 jan. 2005. Disponível em: https://cutt.ly/Mf3s0cO. Acesso em: 5 nov. 2019.

BRASIL. Portaria Normativa $n^{\circ} 2$, de 26 de janeiro de 2010. Institui e regulamenta o sistema de seleção unificada, sistema informatizado gerenciado pelo Ministério da Educação, para seleção de candidatos a vagas em cursos de graduação disponibilizadas pelas instituições públicas de educação superior dele participantes. Diário Oficial da União: seção 1, Brasília, n. 18, 27 jan. 2010. Disponível em: https://cutt.ly/nf3sVTM. Acesso em: 5 nov. 2019. 
COUTINHO, F. A.; SOARES, A. G.; BRAGA, S. A. M. Análise do valor didático de imagens presentes em livros de biologia para o ensino médio. Revista Brasileira de Pesquisa em Educação em Ciências, Belo Horizonte, v. 10, n. 3, p. 1-18, 2010. Disponível em: https://cutt.ly/qf3s7xi. Acesso em: 29 set. 2020.

GOMES, E. C. A escrita na história da humanidade. Dialógica, Manaus, v. 1, n. 3, p. 1-17, 2007. Disponível em: https://cutt.ly/7f3dau7. Acesso em: 29 set. 2020.

INEP. Edital n. ${ }^{\circ} 13$, de 7 de abril de 2017. Exame Nacional do Ensino Médio. Diário Oficial da União: seção 3, Brasília, n. 69, p. 47, 10 abr. 2017a. Disponível em: https://cutt.ly/rf3dkd6. Acesso em: 5 nov. 2019.

INEP. Matrizes de referência. Brasília: INEP, 2015. Disponível em: http://portal.inep.gov.br/web/guest/ matriz-de-referencia. Acesso em: 5 nov. 2019.

INEP. Portaria n. ${ }^{\circ}$ 109, de 27 de maio de 2009. Diário Oficial da União: seção 1, Brasília, n. 100, p. 56, 28 maio 2009. Disponível em: https://cutt.ly/xf3dzJo. Acesso em: 5 nov. 2019.

KRESS, G.; VAN LEEUWEN, T. Reading images: the grammar of visual design. London: Routledge, 1996.

MAYER, R. E. Cognitive theory of multimedia learning. In: The Cambridge handbook of multimedia learning. Cambridge: Cambridge University Press, 2005. p. 31-48.

MAYER, R. E. Multimedia learning. Cambridge: Cambridge University Press, 2001.

MAYER, R. E. Multimedia learning. 2. ed. Cambridge: Cambridge University Press, 2009.

NASCIMENTO, F. S.; COUTINHO, T. C.; PINHEIRO, J. A. Exame Nacional do Ensino Médio - Enem: um olhar dos discentes do $3^{\circ}$ ano do ensino médio e sua preparação para o ingresso no ensino superior. Educação em Revista, Marília, v. 14, n. 2, p. 69-92, 2013. DOl: https://doi.org/10.36311/22365192.2013.v14n2.3561.

NEVES, R. F. Abordagem do conceito de célula: uma investigação a partir das contribuições do modelo de reconstrução educacional (MRE). 2015. 264 f. Tese (Doutorado em Ensino de Ciências e Matemática) - Universidade Federal Rural de Pernambuco, Recife, 2015.

SANTAELLA, L.; NÖTH, W. Imagem: cognição, semiótica, mídia. São Paulo: Iluminuras, 2008.

SILVA, H. C. Lendo imagens na educação científica: construção e realidade. Pro-Posições, Campinas, v. 17, n. 1, p. 71-83, 2006.

SILVA, R. R. A transposição com expansão do conteúdo do livro didático de matemática para o tablet na perspectiva da teoria cognitiva de aprendizagem multimídia. 2013. 152f. Dissertação (Mestrado em Multiunidades em Ensino de Ciências e Matemática) - Faculdade de Educação, Universidade Estadual de Campinas, Campinas, 2013.

SMIT, J. W. A representação da imagem. Informare, Rio de Janeiro, v. 2, n. 2, p. 28-36, 1996.

SOUZA, L. H. P. As imagens fotográficas de saúde no livro didático de ciências. In: ENCONTRO NACIONAL DE PESQUISA EM EDUCAÇÃO EM CIÊNCIAS, 8., 2011, Campinas, São Paulo. Anais [...]. Campinas: ENPEC, 2011. Disponível em: http://www.nutes.ufrj.br/abrapec/viiienpec/resumos/ R0638-1.pdf. Acesso em: 5 nov. 2019. 